\title{
Unequal gender relations in the practices of girl marriage in poor families at East Java Province
}

\section{Relasi gender yang tidak setara dalam praktik pernikahan anak perempuan pada keluarga miskin di Provinsi Jawa Timur}

\author{
Emy Susanti \\ Department of Sociology, Faculty of Social and Political Sciences, Universitas Airlangga \\ Address: Kampus B Dharmawangsa Dalam, Airlangga, Gubeng, Surabaya 60286 \\ E-mail: emy_susanti@yahoo.com
}

\begin{abstract}
The practice of girl marriage in Indonesia is a social reality that has been going on from generation to generation. Although the average level of education in Indonesia is increasing and the government has limited the practice of child marriage, in some areas of East Java province the tendency of parents to marry off their underage girls remains. This study aims to identify gender-based power relations within the practices of girl marriage in poor family in East Java province. This study is also aimed at revealing how the social reproduction of gender inequality values takes place in the girl marriage practices. This research was done by using qualitative method which was supported with quantitative data. This study shows that the victims of early marriage practices are girls. Gender-based-power relations between young wives with husbands, parents and in-laws are not equal. The unequal gender-based power relations in girl marriage practices in poor family are relate to limitation of knowledge and reproduce of power. The unequal gender relations are continuously reproduced through the imposition of negative social labeling on girls. The prevention of girl marriage requires a comprehensive approach by addressing the social and cultural values, especially promoting equal gender relations. One of the solutions is empowerment based on equal gender perspective.
\end{abstract}

Keywords: girls; early marriage; poverty; power relations; gender inequality

\begin{abstract}
Abstrak
Praktik pernikahan anak perempuan di Indonesia adalah realitas sosial yang telah terjadi dari generasi ke generasi. Meskipun tingkat rata-rata pendidikan di Indonesia meningkat dan pemerintah membatasi praktik pernikahan anak, di beberapa daerah di Provinsi Jawa Timur kecenderungan orang tua untuk menikahi anak perempuan mereka yang masih di bawah umur tetap ada. Penelitian ini bertujuan untuk mengidentifikasi relasi kekuasaan berbasis gender dalam praktik perkawinan gadis di keluarga miskin di provinsi Jawa Timur. Penelitian ini juga bertujuan untuk mengungkapkan bagaimana reproduksi sosial nilai-nilai ketidaksetaraan gender terjadi dalam praktik perkawinan perempuan. Penelitian ini dilakukan dengan menggunakan metode kualitatifyang didukung dengan data kuantitatif. Studi ini menunjukkan bahwa korban praktik pernikahan dini adalah anak perempuan. Hubungan kekuasaan berbasis gender antara istri muda dengan suami, orang tua dan mertua tidak sama. Hubungan kekuasaan berbasis gender yang tidak setara dalam praktik perkawinan perempuan dalam keluarga miskin berhubungan dengan keterbatasan pengetahuan dan reproduksi kekuasaan. Hubungan gender yang tidak seimbang terus direproduksi melalui pengenaan pelabelan sosial negatif pada anak perempuan. Pencegahan perkawinan gadis membutuhkan pendekatan yang komprehensif dengan mengatasi nilai-nilai sosial dan budaya, terutama mempromosikan hubungan jender yang setara. Salah satu solusinya adalah pemberdayaan berdasarkan perspektif gender yang setara.
\end{abstract}

Kata kunci: perempuan; pernikahan dini; kemiskinan; hubungan kekuasaan; ketidaksetaraan gender

\section{Introduction}

The practice of girl marriage in Indonesia is a social reality that has been going on from generation to generation. Although the average level of education in Indonesia is increasing and the government has limited the practice of child marriage, in some areas of East Java province the tendency of parents to marry off their underage girls remains. In poor families, there are many school-age girls who do not attend education institutions. Compared to other regions in Indonesia, data from Indonesian 
Central Bureau of Statistics show that the marriage rate of girls in East Java Province is quite high, especially in rural areas (BPS 2016). A few states such as Saudi Arabia, Yemen, and Iran still follow Sharia law, which specifies reaching puberty, not age, as designating that someone is mature enough to get married (Al-Hakami \& McLaughlin 2016).Instead, gender inequality in sub-Saharan Africa may manifest most insidiously within marriage and may be reinforced by the marriage process itself, particularly the related exchange of bride-wealth payments (Boni 2001; Dodoo \& Beisel 2005).

The marriage process and the exchange of bridewealth payments contributes to adolescent boys' expectations of increased male authority in marriage (Frost \& Dodoo 2010). The rural women usually had little income, and many of them relied on their husband's incomes. They believe that husband's role is identified as protecting wife and financially supporting the family (Thi vu 2017).In Africa, South-east Asia, The Middle East and Latin America, many families arrange their daughters' marriages to improve their economic situation (Bravo 2014).In Morocco and Jordan the number of marriages of minors has been steadily increasing.It causemarriage of minors aapproved by the court, between 86 and 93 percent between 2007 and 2012 (Prettitore 2015). Data show that marriages involving under-aged girls tend to result in divorce and re-marriage.

The practice of underage marriage is a violation of human rights, especially the rights of women and children (Parsons et al. 2015). Girls who marry early have little decision-making power within the marital home, a greater likelihood of school dropout and illiteracy, lower labor force participation and earnings, and less control over productive household assets (Parsons et al. 2015). Child marriage remains highly prevalent today and it has substantial negative development impacts in the areas of education, labor force participation, health, violence, and empowerment (Klugman et al. 2014).

Previous research demonstrated that girls who are involved in the practice of child marriage in East Java province come from poor families. The parents encourage the girls to marry in order to lessen the family's economic burden, even though they are not yet 18 years old and are still attending school (Susanti et al. 2017). Furthermore, Indonesia Population Data Survey (IDHS/SDKI) in 2007 showed that the number of marriage cases of couples under 16 years in East Java reached $39.4 \%$. In rural areas, marriage is often done as soon as the girl gets her first period. Meanwhile, data from Indonesian Central Bureau of Statistics (BPS2016) states that one of three girls in Java married for the first time under the age of 16, especially in West Java and East Java (about 25\%). Today, this practices of girl marriages has been going in Indonesia about $23 \%$ (UNICEF 2016).

According to the traditions of the people in East Java Province, the marriage of the girls under the age of 18 is normal, especially in poor families. It is common that parents to marry off their daughter who has already got their period or graduated from elementary school. Child marriage is defined as a legal and custom union involving boys or girls under the age of 18 . However, the Convention on the Rights of the Child, the Convention on the Elimination of all Forms of Discrimination against Women, the Universal Declaration of Human Rights, and the recent resolution of the United Nations Human Rights Council discusses the girl marriage because it is considered as a violation of human rights.

The social implications of girl marriage are very complex. Previous studies have proved that there is a correlation between marriage and high divorce rates. The data released by BPS showed that in Indonesia, the divorce rate of girls, who married at the age of 10-14 years, is twice higher compared to that of girls who married at the age of 15-19 years. This means that the younger the girls get married, the higher of the risk of divorce. Many studies revealed that girl marriage cause maternal deaths (MMR) due to the lack of information about healthy reproduction so that the young mothers are at a high risk of dying in childbirth. In addition, the girls are generally psychologically immature and are not ready to become mothers. Thus, they often do not provide proper treatment and care to their children due to insufficient knowledge on the matte (Le Strat 2011).

The government actually has made a policy to prevent the marriage of underage girls in Indonesia especially in poor families. Unfortunately, the practice has remained and has caused suffering for the girls in East Java. For the reason, it is essential to understand the reality of underage girl marriage in 
East Java province, especially from the poor families. This study is important because the Indonesian government policies and the law about child marriage are not significant to reduce the practice of child marriage. A comprehensive approach is needed to prevent the underage girl marriage, such as understanding the change of socio-cultural values, especially in poor families.

The social relations of men and women called as gender relations place women in the domestic sphere and men in the public sphere. This has happened for years and has led to gender inequality. Unfortunately, the inequality is still ongoing because many people think that it is "natural and noble', whereas the social reality shows how gender inequality has led to gender discrimination and even gender-based violence that are often perpetuated.

Previous study in Javanese poor families proved that girls experience lack of educational opportunities, and attention compared to boys. They are required to take a big responsibility on domestic tasks so that the number of girl drop-outs from school is high. The girls are prepared for marriage, but boys continue pursuing higher education and are prepared to carry out public roles (Susanti 2007). Various studies also show that gender discrimination has led to women violence in various forms. Ironically, the women are not aware of it because the violence is part of socio-cultural values and governed by social norms in the society. Violence against women can be experienced in every stage of women's life time. Among the categories of violence against women is child marriage because it is a 'forced marriage' (Jain \& Kurz 2007).

Different from other studies which focus on the issues of health, violence, education and Human Rights, this study more focuses on the gender issues of girl marriage practices from sociological perspective. Moreover, this study focuses on the girls only, which married without seeing the age of their husbands. Gender relation is a result of social construction, which may different in places and time. Social construction is shaped through a long process and social discourse which then becomes a 'gender ideology'.

In the theory of the genealogy of power, Michel Foucault explains that sexuality is a special transfer point of power relations. He views the relationship between power relations and sexuality in order to define the power-knowledge-pleasure regime that sustains discourse on human sexuality as part of the world. The power of sexuality is not located in a single major source, but in a variety of micro settings. Power over life has two forms, namely: (a) the "anatomical-political anatomy of the human body", which aims to discipline the human body and its sexuality; (b) the "bio-political population"which aims to control and regulate population growth, health, life expectancy and so on. Foucault sees that both forms of power trigger a consciousness among society to consider life as a political object (Foucault 2002).

Foucault illustrates that power is not centered. Power is everywhere, not because power covers everything, but because power comes from everywhere. Power is not defined as the power exerted from a country or social institution and not from something related to social structure. The real power is the complex situation of life in society. Foucault said that the mastery of women initially comes from male mastery over the female body. Through sufficient knowledge of sexuality, people will use greater power in their own lives. The power is not only focused on who is in power and who is dominated in economic scope. According to Foucault, power is already in the wider domain, so that the change in power relations does not naturally change the position of men to be replaced by women, or vice versa. However, this change occurs only on gender roles. Foucault's theory can explain that power is not only found in the organization or the binding structure, but also in regard to the control of the body and behavior to produce dominance in domestic space (Foucault 2002).

In society, good and bad deeds are constructed based on socio-cultural values in the community. Labeling theory (Becker 2008) emphasizes two main points: first, it explains why and how a person is labeled, and secondly, it explains the effect of the label on the person. The labeling will generate a lot of attention from the society. Labeling theory has a different orientation on social 
deviation compared to other theories. Labeling theory believes that what is good or bad depends on the observer's view because members of different groups might see differently what is called good and feasible under certain circumstances.

Labeling theory is defined as perspectives in labeling norms, which means that the main cause social label can be found when the labeling by the community is attached to certain members of the group. A person or group of persons is determined a social label by the act of labeling by another person, or by a label specified in the society. It can be on whom the label has been specifically specified. Thus, an important dimension of deviation is in the reactions of society, not to the quality of action itself. Labeling theory emphasizes the importance of negative social sanctions associated with individual pressures. Analysis of labeling is focused on the reactions of others, meaning that there are people who give a definition, a title or label to the individual or actions judged negative by others. Labeling theory can be used to explain how girls get negative stamps when they are not married at a certain age.

This study attempts to understand the reality of girl marriage in East Java province in order to formulate various programs to prevent and reduce child marriages in poor families. This study attempts to reveal how gender-based power relations and social reproduction of gender inequality values take place in the child marriage in East Java province. Understanding the reality of girl marriage could provide a solution and save the lives of the upcoming generation.

\section{Research Method}

This study applied qualitative research which is supported by quantitative data. The study was conducted to scrutinize poor families in two regencies in East Java province, namely Bangkalan with Maduranese culture and Blitar with Javanese culture. The subjects of this study were people involved in the girl marriage, i.e. victims, parents of the victim, family members of the victim, neighbors, and community leaders.

The first stage of primary data collection was carried out by conducting interviews using questionnaires on 100 parents who have daughters (50 respondents in each district studied). The second stage of primary data collection was done by conducting in-depth interviews using interview guidance on 20 informants (early marriage women, their parents and community leaders).

\section{Result and Discussion}

\section{Gender-based power relations in the practices of girl marriage in the poor family}

The results of this study indicate that the social implications for the girls who get married at an early age are very complex. The girls as young wives do not have a bargaining position to make decisions about various aspects of their life. The power relations within the household are not equal because the power is in the hands of the husband. In addition, the parent in-laws are also important in determining family life because they control the access to the outside world. Compared to women who get married at adult age, the underage girls have weaker controls on household resources, limitation on their time and access to health information and services, including mental health, selfconfidence, and self-esteem.

The practice of early marriage for the underage girls among poor families is considered to reduce the burden of the family economy. Some married women in under 18 years of age revealed that their family cannot afford to send them to school. The results of the study indicates that girls are married at a very young age. Both in Bangkalan and Blitar, girls are married at the age of children or young teenagers (under 18 years of age). Most of them even got married at the age under 14 in Bangkalan $74 \%$ and Blitar $68 \%$ (Table 1). It can be seen that the girls who get married under the age of 18 years are very common and it is often regarded as a part of their social and cultural norms. The parents will marry off their girls just after the first menstruation or graduation from elementary school. The previous studies have shown that early age marriage tends to be in harmonious. It is proved that the younger the girls get married, the greater the risk of divorce (Gemignani \& Wodon 2015). 
Table 1.

The age of marriage of the girls

\begin{tabular}{lcccc}
\hline \multirow{2}{*}{ Age } & \multicolumn{2}{c}{ Bangkalan } & \multicolumn{2}{c}{ Blitar } \\
\cline { 2 - 5 } & $\mathbf{f}$ & $\mathbf{\%}$ & $\mathbf{f}$ & $\mathbf{\%}$ \\
\hline 11 years old & 8 & 16 & 10 & 20 \\
12 years old & 12 & 24 & 10 & 20 \\
13 years old & 8 & 16 & 9 & 18 \\
14 years old & 9 & 18 & 5 & 10 \\
15 years old & 3 & 6 & 9 & 18 \\
16 years old & 6 & 12 & 1 & 2 \\
17 years old & 2 & 4 & 3 & 6 \\
18 years old & 2 & 4 & 3 & 6 \\
\hline Total & $\mathbf{5 0}$ & $\mathbf{1 0 0}$ & $\mathbf{5 0}$ & $\mathbf{1 0 0}$ \\
\hline \multicolumn{2}{c}{ Source: Primary Data } & &
\end{tabular}

This study shows that since the girls get married, they drop out from school so that they actually suffer from the loss of rights as children. The data from the study demonstrates that the highest education of the most girls who got married at an early age is only elementary school; some even did not complete primary school $66 \%$. After marriage, they do not have autonomy in deciding whether they should continue or return to school. As a result, their ability in reading and counting is very limited. The marriage makes the young girls are burdened with domestic obligations and this makes them indecisive to reach their own goals. Girl marriage is particularly vulnerable to violations of the girls' rights as children because they are no longer categorized as such. Thus, the underage married girls potentially become worse off after marriage because they are bound in it and the domestic duties and cannot attend school.

From the data of the study, it is obtained that $80 \%$ of girls after marriage continue to work and their salary is relatively small. Most of their income is below 900 thousand rupiah 52\% in Bangkalan regency and 58\% in Blitar regency. Meanwhile, their average expenditure ofthe basic necessities which are managed by the wives is below 1 million rupiah/month (equivalent to US $\$ 100 ; 66 \%$ in Bangkalan regency and $66 \%$ in Blitar regency). In short, the money which is managed by the wives per month is roughly not enough for their household's revenue. It means that the majority of women, who are married in early age, only have autonomy on their own income. Thus, the study implies that early marriage of the underage girls cannot contribute to the economy of their households and their extended family. This fact is different from other study on young couples in Vietnam which found that young wives relied on their husband's incomes and they believe that husband's role is identified as protecting wife and financially supporting the family (Thi vu 2017).

This study revealed that the parents still contribute economically to the family of their girls in the form of basic food commodities and in cash. Unfortunately, the people in poor families label the young girls who are not yet married as old spinsters and the like. In addition, many parents hope that by marrying off their girls at an early age will help the household income. In fact, the girl marriage is actually burdening the economy of the family. The data from this study shows that the husband's income is inadequate to meet the needs of the household and children. There are even husbands who do not work, especially in Bangkalan regency. The husbands usually work in low-income occupations such as farmers, construction workers, traders, drivers, motorcycle taxi drivers, and migrant workers.

From the internal poverty theory, this study found that the people in the poor community do not have enough resources (lacking skills and education). In term of external poverty theory, it is obtained that the families experiencing poverty for several generations (Chambers 1987). The study also demonstrates the absence of specific policies that provide opportunities for the poor. As shown in previous studies which is related to the cultural life in the poor family, marrying off girls at a young 
age, under age 18 years, is considered to lessen economic burden for the big family. Mrs. Rub, a 40 years old mother has experienced of early marriage told about her daughter:

"Getting married is good, and it is safer for my girl ... because she has husband who can protect and be responsible for her .... She has new family, and a husband who can help and feed her, because I cannot feed her anymore. When her father was around, he used to give her money but not anymore. So it really reduces the burden of family...".

In addition, the study found that the early marriage girls are psychologically immature and not ready to be a mother. They do not have enough knowledge to care for their children so that their children are not properly taken care of. The government actually has issued policy to prevent early marriage in Indonesia, especially in poor families, but child marriage in East Java province remains common. In many cases, it is proved that the early marriage causes more harm and suffering, especially for girls.

The data of the study shows that the early marriage couple are still indebted to the parents and their brother after marriage (48\% in Bangkalan regency; $42 \%$ in Blitar regency). The debt is in form of basic needs and processed food in order to meet the daily needs (67\% in Bangkalan regency; $50 \%$ in Blitar regency). Thus, the reason for marrying off the girls at an early age with the aim of helping the family economy does not happen. The data obtained shows the opposite, that the girls after marriage is still economically dependent on their parents and siblings.

For the young girls, the early marriage stops their formal education which means they cannot acquire more knowledge and useful skills enabling them to be productive. They also lost social networks and social support. Girls have power when they could decide their own life and act without fear of violence and revenge. Early married couples are often vulnerable in several aspects: they are young, poor, and less educated. It influences the way they manage their assets and resources so that it reduced their ability in decision making. Early marriage usually puts the girls under the control of their husbands and frequently of the parent in-laws so that the girls has no opportunity to voice their own opinions, existence and plans.

The practices of girl marriage actually make the life of the girls getting worse. The girls are locked in domestic jobs and childcare so that they do not have opportunity to do productive activities. A woman who is getting married at young age said that she used to help the parents work in the fields when she was single and could earn revenue. After getting married, she can no longer work in the fields, while the expenditure of her husband's money is very limited and even not enough to buy milk and supplementary foods for children. The facts prove that girls become of "victim" of the early marriage.

Table 2 shows that the organizer of all matters related to the underage girl marriage is not the bride, but the parents and family of the men $80 \%$ in Bangkalan regency and $56 \%$ in Blitar regency. This proves that the marriage is to meet the wishes of the family and it is not a voluntary decision of the girls to get married.

Table 2.

Actors who play a role in the underage marriage

\begin{tabular}{lcccc}
\hline \multirow{2}{*}{ Actor } & \multicolumn{2}{c}{ Bangkalan } & \multicolumn{2}{c}{ Blitar } \\
\cline { 2 - 5 } & $\mathbf{f}$ & $\mathbf{\%}$ & $\mathbf{f}$ & $\mathbf{\%}$ \\
\hline The in-law family & 22 & 44 & 7 & 14 \\
Parents of the bride & 18 & 36 & 21 & 42 \\
Both the bride and the groom & 3 & 6 & 3 & 6 \\
Groom & 7 & 14 & 19 & 38 \\
Total & $\mathbf{5 0}$ & $\mathbf{1 0 0}$ & $\mathbf{5 0}$ & $\mathbf{1 0 0}$ \\
\hline \multicolumn{4}{c}{ Source: Primary Data }
\end{tabular}

Mrs. Ta, 17 years old, the girl who marry at the early age have less authority for decision-making in their household. She said that her whole life is only to take care of the household and children, as described follows: 
"Of course there are changes. How does it feel? ....It feels...so busy...now. NowI have to take care of everything. I do it alone. Caring for the children, husband, rice field (glancing toward her grandmother)".

In the household, a young wife typically has little bargaining power and authority to make decisions about various aspects of life. Her husband and parent in laws control her access and participation in the public space. According to Foucault (2002), the gender-based power relations in a family is the power relations between husband and wife. This study found that in the household, a young wife has less bargaining power to make decisions about various aspects of life. The gender-power relations in the household are not equal in which the power is in the husband and parent in law who control the access to life outside the house. Gender-based power relations are not equal and poverty is not improving afterthe early marriage of the girls. The study shows the power relations between husband and young wife based on a patriarchal culture in which the husband has the power to control household and his young wife. It is also revealed from the result of the study that in the practices of girl marriage, the process of the exclusion of girls in the public sphere affects the young wife's behavior in negotiating the role and relationship in their domestic space, in this context is the family and their husband.

\section{Reproduction of the unequal gender relations in the practices of girl marriage}

The practice of girl marriage is the result of reproduction of social and cultural values that exist in the society. The marriage has own mechanism so that it goes on. The mechanism keeps running because of the actors who play a role in the practice of underage marriage as described previously. The practice is also related to their knowledge about the ideal age for girls to get married based on the law and tradition in each area where early marriage happens. The elders and parents are the actors who contribute to the early marriage. They play important role in decision making, arranging and managing the marriage. However, they are also the victims of social construction and social label. The following data are the mechanism of reproduction of social and cultural values and the role of the actor the practice of the underage girl marriages in Bangkalan regency and Blitar regency.

The data from this study indicate that the mothers of the underage girls have the same experience to get married at a very young age. Most of them were married at the age of 11 years up to 13 years in Bangkalan regency $60 \%$ and Blitar regency $42 \%$ which means their age at the time of marriage is younger compared to their daughters who get married at the age of 11 to 14 years. Nevertheless, the marriage age of the girls in poor families have remained relatively early, which is 3-4 years under the ideal age of marriage, 18 years old.

The social values of unequal gender relations between women and men in the practice of the underage girl marriage of women are continuously reproduced as if it did not considerthe 'harm' for the girls. In addition, the study shows that the aim of the early marriage is to meet the gender values in the family where a divorcee is seen much more respectable than the unmarried status which often means a label as old spinster. The gender values treat differently between boys and girls, as stated by Mrs. Nur, 24 th, from Bangkalan, early married wife describes the situation as follows:

"Here, a girl aged 20 yearsis categorized as a spinster, ... A boy of the same age but still not married is not problem because the people think he wants to work and settle. Again, a girl becomes victim of the mocking".

Some girls, who get married at an early age, said that they are not asked about their opinion concerning of the prospective husband at the arranged marriage, the wedding time, and the things related to the wedding rituals. The girls just follow and obey to the values of the biased gender, which see them as objects not subjects of the early marriage.

Gender values that sustain unequal gender relations between men and women are continuously reproduced from generation to generation. Girls should get married as soon as possible after menstruation if they do not want to be labeled as 'spinster'. A mother told that the practice of early marriage has been done for years. Mrs. Sum, 54 years, mother of underage marriage girl said; 
“... Getting married for the young girls had been done from the era of my great grandmother. My mother was married at 13 years and even there was engagement at that time. We have to say yes when someone comes to propose...the people here believe that it is not good to refuse the proposal.If a girl refuses the proposal she will not get married for the rest of her life and becomes spinster. Even the boy will send black magic to the girl who refused him because of his broken heart.....".

The label of spinster is so haunting and passed down from one generation to the next generation. Using Labeling Theory (Becker 2008), it is revealed from the study that the main social label can be found when the labeling by the community is attached to certain members of the group, namely 'old spinster' label for the girls who are not married after 20 years old. The social labels are also embedded in society regarding to the various aspects of girls' lives and practices of underage marriage. A person or group of persons is determined to be an old spinster by the act of labeling by another person, or by a label specified in this society.

Labeling theory emphasizes the importance of negative social sanctions associated with individual pressures and is focused on the reactions of others. The study shows that there are people who give a definition, a title or label to the girls as spinster and judged negative by community. Using Labeling theory help to explain how girls get negative stamps when they are not married at a certain age. The category of age depends on each community. In this community gives social sanction to the girls who are not married at 17 years old in which it triggers the continuing practice of early marriage on girls.

Having a status of divorce in the poor families is generally considered far more honorable than having the status of unmarried women, which is often stigmatized as spinster. On the contrary, for girls, divorce causes them to suffer because they lose their rights as children. Their status often closes the opportunity to obtain a life in accordance with their ideals. Girls aged 15 or 16, who have children and then undergo marriage dissolution, become divorcees at a very young age. The status as young divorcee makes them very vulnerable to violations of their rights as children because they are legally no longer categorized as child.

In addition, this study found that the elders and the parents in the poor family do not understand about the regulation of the age of marriage under the Marriage Law. It is obtained from the data of this study that most parents do not know about the age limit in the law in Bangkalan 54\% regency and Blitar regency $24 \%$. They only know that the time for the girls to get married is the coming of the period (in Bangkalan regency 28\% and Blitar regency $42 \%$ ). Similarly, previous study in Saudi Arabia shows that follow Sharia law, specifies reaching puberty, not age, as designating that someone is mature enough to get married (Al- Hakami \& McLaughlin 2016).

Due to the low level of education, marriage girls are often not considered by her husband and inlaws to make and manage money and to make the decision about the household finance. They have less control over their income. Isolation from school, friends and workplace makes them hard to get access to social support which is very important for their emotional health. Early marriage limits the married girls to get the access to social capital and social network as a means to increase potential income. The previous studies revealed that the young married girls cannot fight against physical and emotional harassment by their husbands or in-laws in their own homes (Anand et al. 2012). Moreover, other studies in Pakistan and France families show that early marriages relate to the incident of domestic violence (Nasrullah \& Zakar 2014; Falb et al. 2015). This study also reveals that after marriage, the young wives experience more severe sufferings and trapped in poverty economically and socially.

The lack of autonomy among the young wives significantly affects their economy so that they cannot allocate more money to education and health, for example. Only trough participation and decision making, a girl's aspiration for her children can be materialized. The lack of girl's autonomy in issues related to child caring could influence the children's life before birth, because there is a lack of power to control in reproduction decision, including distance between births and the number of children. 
Next, the early marriage for the underage girls reinforces the unequal values and gender norms to the next generation. They can lose of opportunity to improve their chances of success in the future because of the lack of public investment in social services and programs. This study reveals that the role of women as primary caregivers blocks the young wives to work outside the house and limit her chance to work. Because this limitation is encountered in early stages of marriage, child marriage affects the girls' potential to enter the workforce. One of previous studies showed that early marriage contributes to the high number of premature child birth, short birth spacing, and higher number of children (Nour 2009).

The traditional values and norms which are embedded in the child marriage have an impact on decreasing the labor force participation rate. The low participation in paid work can increase household poverty, vulnerability to economic shock, the diversity of low income, and provide incentives in the short-term allocation decisions at the expense of long-term investment in human and physical capital. It also causes low level of physical health, reduced investment, and low productivity, which then affect economic growth. These factors, in turn, may have an significant impact, leading to worse health among children and lower investment in education and the accumulation of other human resources, as well as the ability toovercome obstacles, such as diseases and the possibility of early marriage in the next generation. The low worth of girls and the social label attached to them will perpetuate the practices of girl marriage.

The early marriage girls have little decision-making power, higher possibility of dropping out of school, being illiterate, having lower income and less control over household assets. The former research demonstrates that becoming a mother at a very young age will make their children prone to poor health and malnutrition. The young wives giving birth at early age will experience more dangerous, difficult, and complicated birth, and tend to have children with poorer health condition and education than their peers (Field and Ambrus 2008). This study found that power relations between young wives and their husband, parents and in-laws are very unequal. The consequences of child marriage are found to be more severe in girls.

Previous study also found that child marriage has substantial negative impacts in the areas of education, labor force participation, health, violence, and empowerment (Klugman et al. 2014). Moreover, Child marriage gives a deep and wide impact at national and global level in forms of potential revenue loss andpoverty inheritance between generations. Unequal gender-based power relation is going on in form of child marriage practices in poor families. Gender-based power is related to rights limiting this power and knowledge resulted and passed on through power, which in turn reproduces the power (Foucault 2002).

Finally, it can be seen from the research results that the victims who suffer the most in the early marriage are the girls. The social norms supporting early marriage in girls are reproduced through various mechanisms. The economic impact and marriage cost tend to be higher in girls marrying earlier, in their children, their family, their family, and in society as whole.

The research results revealed several points as follows: 1) the practice of early marriage among girls is still done for economic reasons with a negative social label imposed on girls; 2) the underage girls become the victims of early marriage in which the power relationship with her husband and in-laws are not equal; 3) the unequal gender relation between underage girls and their husbands as well as the elders are reproduced and passed on from generation to generation. The economic condition of the girls undergone early marriage is worsened by multidimensional problems. The girls even had better condition before the marriage. After marriage, the girls drop out from school, have malnourished children, and do not improve their parents' economic condition.

\section{Conclusion}

There is no significant difference between the poor families in Bangkalan regency with Maduranese culture and Blitar regency with Javanese culture, all poor families assume that girl marriage is a 
way out of poverty. In fact, the study shows that the early marriage makes the poverty worse. The girls are trapped in household duties so that they cannot engage in productive activities. Before getting married, the girls could help their parents to earn money by working in the fields but they can no longer do it after marriage. On the other hand, their husband cannot give them enough money to buy milk and supplementary food for their children. It means that the girls become victims of early marriage. In addition, the gender-based power relations place them as subordinates to their husbands and in-laws.

The underage girls are suffering because they lost their rights as children. They are burdened with many responsibilities in domestic tasks so that they do not have opportunity to pursue their own dreams. Underage married girls are vulnerable to violations of their rights as children because they cannot be considered as children anymore after marriage. Thus, the girls' life is potentially worsened off because they are trapped in domestic tasks and unable to continue their education. This study shows that gender-based power relation between young wives with husbands, parents and in-laws are not equal. The unequal gender-based power relations in girl marriage practices in poor families are relate to limitation of knowledge and are continuously reproduced through the imposition of negative social labeling on girls. This study found that Indonesian government policies and the marriage law cannot easily reduce practices of girl marriage. The prevention of girl marriage requires a comprehensive approach by addressing the social and cultural values, especially promoting equal gender relations. One of the solutions is empowerment based on equal gender perspective.

\section{Acknowledgments}

Many thanks go to The Ministry of Research and Higher Education Republic of Indonesia. Special thanks go to people who agreed to participate in the study.

\section{References}

Al-Hakami H \& McLaughlin K (2016) Debatable marriages: Marriage and child marriage in Saudi Arabia. Marriage \& Family Review 52 (7):654-664.

Anand S, Desmond C, Fuje H, \& Marques N (2012) The Cost of Inaction: Case Studies from Rwanda and Angola. Cambridge: Harvard University Press.

BPS (2016) Kemajuan yang Tertunda: Analisis Data Perkawinan Usia Anak di Indonesia. Jakarta: Badan Pusat Statistik.

Becker HS (2008) Outsiders: Studies in Sociology of Deviance Kindle Edition. London: Free Press.

Boni S (2001) Twentieth-century transformations in notions of gender, parenthood, and marriage in southern Ghana: A critique of the hypothesis of retrograde steps for Akan women. History in Africa 28:15-41.

Bravo MMP, Martinez PA, \& Ruiz IJ (2014) Arranged marriages: Women for sale. Procedia - Social and Behavioral Sciences, 132:564-569.

Chambers R (1987) Rural Development Starting From Behind. Jakarta: LP3ES.

Dodoo FN \& Beisel N (2005) Africa in American sociology: Invisibility, opportunity and obligation. Social Forces 84 (1):595-606.

Falb KL, Annan J, Kpebo D, Cole H, Willie T, Xuan Z, Raj A, \& Andgupta J (2015) Differential impacts of an intimate partner violence prevention program based on child marriage status in Rural Cote d'Ivoire. Journal of Adolescent Health 57:553-558.

Field E \& Ambrus A (2008) Early marriage age of menarche, and female schooling attainment in Bangladesh. Journal of Political Economy 116 (5):881-930.

Foucault M (2002) Power / Knowledge: Selected Interviews \& Other Writings 1972-1977. New York: The Harvaster Press.

Frost AE \& Dodoo NA (2010) The man comes to marry the woman: Exploring adolescent boys' gendered expectations for bridewealth and marriage among the Akwapim of Southern Ghana. Marriage \& Family Review 46 (1-2):41-59. 
Gemignani R \& Wodon Q (2015) Child marriage and faith affiliation in Sub-Saharan Africa: Stylized facts and heterogeneity. The Review of Faith \& International Affairs 13 (3):14-47.

Jain S \& Kurz K (2007) New Insights on Preventing Child Marriage: A Global Analysis of Factors and Programs. Washington, DC: ICRW.

Le Strat Y, Dubertret C, \& Le Foll B (2011) Child marriage in the United States and its association with mental health in women. Pediatrics 128 (3):524-530.

Klugman J, Hanmer L, Twigg S, Hasan T, \& McCleary-Sills J (2014) Voice and Agency: Empowering Women and Girls for Shared Prosperity. Washington: The World Bank.

Nasrullah M \& Zakar R (2014) Child marriage and its associations with controlling behaviors and spousal violence against adolescent and young women in Pakistan. Journal of Adolescent Health 55 (6):804-809.

Nour NW (2009) Child marriage: A silent health and human rights issue. Review of Obstetrics Gynecology 2 (1):51-56.

Parsons J, Edmeades J, Kes A, Petroni S, Sexton M, \& Wodon Q (2015) Economic impacts of child marriage: A review of the literature. The Review of Faith \& International Affairs 13 (3):12-22.

Prettitore PS (2015) Family law reform, gender equality, and underage marriage: A view from Morocco and Jordan. The Review of Faith \& International Affairs 13 (3):32-40.

Susanti E \& Mas'udah S (2017) Girl Marriage and The Marginalization of Women in The Cities of East Java. Surabaya: Proceeding International Conference on Urban Studies, Border and Mobility.

Susanti E (2007) Ketimpangan Gender dan Ketidakberdayaan Perempuan Miskin Perkotaan. Surabaya: Insan Cendekia.

Thi Vu T (2017) Meanings of marriage to young people in Vietnam. Marriage \& Family Review 54:1-14.

UNICEF (2016) A Fair Chance for Every Child. New York: The United Nations Children's Fund. 